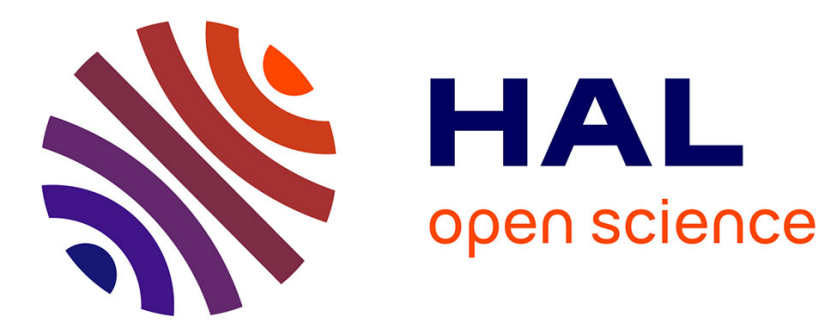

\title{
In Vitro Bone Cell Response to Tensile Mechanical Solicitations: Is There an Optimal Protocol?
}

Timothée Baudequin, Cécile Legallais, Fahmi Bedoui

\section{To cite this version:}

Timothée Baudequin, Cécile Legallais, Fahmi Bedoui. In Vitro Bone Cell Response to Tensile Mechanical Solicitations: Is There an Optimal Protocol?. Biotechnology Journal, 2019, 14 (1), pp.1800358. 10.1002/biot.201800358 . hal-02061207

\section{HAL Id: hal-02061207 https://hal.utc.fr/hal-02061207}

Submitted on 18 Dec 2020

HAL is a multi-disciplinary open access archive for the deposit and dissemination of scientific research documents, whether they are published or not. The documents may come from teaching and research institutions in France or abroad, or from public or private research centers.
L'archive ouverte pluridisciplinaire HAL, est destinée au dépôt et à la diffusion de documents scientifiques de niveau recherche, publiés ou non, émanant des établissements d'enseignement et de recherche français ou étrangers, des laboratoires publics ou privés. 
Mini-Review

In vitro bone cell response to tensile mechanical solicitations: is there an optimal protocol?

Timothée Baudequin ${ }^{1}$

Cécile Legallais ${ }^{1}$

Fahmi Bedoui2

1 Sorbonne universités, Université de technologie de Compiègne, CNRS, UMR 7338 Biomécanique - Bioingénierie, Compiègne, France.

2 Sorbonne universités, Université de technologie de Compiègne, CNRS, UMR 7337 Laboratoire Roberval, Compiègne, France.

Correspondence: Dr. Fahmi Bedoui, Sorbonne universités, Université de technologie de Compiègne, CNRS, UMR 7337 Laboratoire Roberval, Compiègne 60205, France. fahmi.bedoui@utc.fr

Keywords: Bone, mechanical solicitations, scaffolds, stretching, tensile loading.

Abbreviations: ALP, alkaline phosphatase, MSC, Mesenchymal stem cell, PGE2, Prostaglandin E2. 


\begin{abstract}
Bone remodelling is strongly linked to external mechanical signals. Such stimuli are widely used in vitro for bone tissue engineering by applying mechanical solicitations to cell cultures so as to trigger specific cell responses. However, the literature highlights considerable variability in devices and protocols. We reviewed here the major biological, mechanical and technical parameters implemented for in vitro tensile loading applications. The objective was to identify which values were used most, and whether there was an optimal protocol to obtain a functional tissue-engineering construct.

First, we showed that a shift occurred from fundamental comprehension of bone formation, to its application in rebuilt tissues and clinical fields. Despite the lack of standardised protocols, consensual conditions relevant for in vitro bone development, in particular cell differentiation, could be highlighted. Culture processes were guided by physiological considerations, although out-of-range conditions were sometimes used without implying negative results for the development of rebuilt tissue. Consensus can be found on several parameters, such as strain frequency $(1 \mathrm{~Hz})$ or the use of rest periods, but other points have not yet been fully established, especially synergies with other solicitations. We believe the present work will be useful to develop new tissueengineering processes based on stretching.
\end{abstract}




\section{Introduction}

Bone is a living tissue constantly renewed by the combined actions of osteoclasts (responsible for bone resorption) and osteoblasts (bone formation) ${ }^{[1,2] . ~ I t ~ i s ~ w e l l-k n o w n ~}$ that this remodelling is enhanced by mechanical solicitations. Wolff[3] first suggested in 1892 that there was a strong response from bone tissue to external mechanical loading in vivo, leading to resorption or an increase in formation. This behaviour was thus analysed in vitro and, in 1987, Frost proposed the principle of mechanostat[4] to explain the remodelling (Figure S1, Supporting data). In vivo, understanding of what is now mainly called "bone mechanotransduction" progressed year after year from "key early findings"[5], based in particular on the work of Rubin and Lanyon ${ }^{[6-9]}$ (Figure S1, Supporting data). During the mechanotransduction process, a mechanical signal is translated into a biological one, with a strong role played by fluid motion in the lacuna-canalicular network ${ }^{[10]}$ where osteocytes (mature osteoblasts stuck in the extracellular matrix) play the role of sensor cells[11]. Although not all of the mechanisms involved are perfectly understood yet, they have been reviewed many times ${ }^{[5,11-13]}$. In particular, specific strain levels have been proposed as in vivo threshold values for triggering physiological and pathological responses[13].

This knowledge helps researchers in biotechnologies to adapt in vivo mechanisms to in vitro cell cultures, to refine understanding of bone behaviour but also to develop tissue-engineered substitutes ${ }^{[14-16]}$ : cells of interest collected from the patient's body are cultured, mainly in bioreactors, on specific biomaterials ("scaffolds") to provide them with an appropriate environment for improving adhesion, proliferation or differentiation. The rebuilt tissue, a hybrid substitute made of both material and cells, can then be used to heal the same patient[17]. Differentiation relies on changes in the culture environment via the external signals (biochemical, mechanical) applied to the cells[18,19]. We will focus here on 
the specific requirements for in vitro culture steps, prior the implantation, to obtain a functional tissue-engineered construct.

There are different ways of applying mechanical solicitations ${ }^{[20]}$ and many devices have been used and reviewed[20-22]. We have chosen here to focus on the application of tensile loading through deformation of the surface or scaffold on to which cells have adhered and tissue developed. Although compression (due to daily activity and body own weight) and fluid shear stress (due to osteocytes' sensibility in the lacuna-canalicular network $\left.^{[10]}\right)$ are physiological mechanical solicitations in vivo and can be mimicked in laboratory[23-25], tensile stress remains a common and easy method to trigger the cell response in vitro. Over the years, several devices and bioreactors have been proposed to perform such solicitations, in particular by mounting the sample into clamps to stretch it, by bending the culture substrate with a 4-point system or negative pressure (Figure 1A, B, C). However, to date there has been no analysis of their optimal configuration for specific applications. Therefore, the present review focuses on tensile mechanical stimuli for in vitro bone cell cultures to analyse which ranges are the most used and whether an optimal protocol can be proposed to enhance tissue development. To the best of our knowledge, such a specific study analysing culture schedules and mechanical, biological and technical parameters has not yet been carried out.

\section{Methodology}

The first survey of the literature was performed using classical search engines (Pubmed, Scopus, Google Scholar), looking for the appearance in title or abstracts of the keywords: "bone, tensile, mechanical loading, in vitro", leading to around 200 occurrences. It had been decided previously not to include articles from earlier than 1990 because Murray et al[26] was reported as the first publication studying the effect of mechanical load 
on in vitro cell culture ${ }^{[27]}$, following key early in vivo findings ${ }^{[6-9]}$. The publications were found to be spontaneously distributed over the last 3 decades (Figure 1D).

Articles were further selected if they involved in vitro cell cultures, tensile loading and bone tissue, and were focused enough on these points to provide all the information requested (geometry of the mechanical device, frequency and magnitude of strain, etc) and a conclusion on the specific influence of solicitations. This screening led to the selection of 37 articles following the same trend over the years as the first general selection (Figure 1D). A systematic analysis of the in vitro culture steps presented in these papers was therefore performed to highlight major trends or variability, consensus, or processes still under discussion.

\section{General analysis}

\subsection{Bone tissue engineering pillars}

There are generally 3 components considered as essential for growing or building engineered tissue in vitro: cells, biomaterial and environment[28]. Classical 2D and new 3D culture approaches can be used, with various types of cell and different devices generating tensile loading as a specific dynamic environment. The relevant parameters from the above mentioned studies are summarised in Table 1.

\subsubsection{Types of cell and relevant biological responses}

Many different bone cell types have been used, from different species, lineages or differentiation states. The overall distribution is summarised in Figure 1E.

This variety of cell sources can be partly explained by technical issues, such as the presence of animal facilities, ethical considerations, skills, costs, and time. Cell lines are therefore very popular, because of availability and stability, although they cannot claim to 
be completely the same as primary cells. In addition, there is no consensus on a specific line to study, and 8 different cell lines have been reported, the most common being MC3T3-E1[29-33]. Monocytes were also included when investigating osteoclastogenesis $^{[34,35]}$. Primary fibroblasts were also mentioned in 2 cases, corresponding to a control group ${ }^{29]}$ for one and to the specific study of the bone/tendon interface ${ }^{[36]}$ for the other.

For a very large number of articles, the biological analysis focused mainly on the functionality or differentiation state of the tissues or cell populations at the end of the culture period. Authors investigated differentiation states through gene expression analysis, production of specific proteins (such as osteocalcin or osteopontin), ECM deposition, alkaline phosphatase (ALP) activity, mineralisation, and bone nodule formation. In the case of co-culture studies or when the balance with other functions was explored, markers of other lineages were also analysed (for instance osteoclastogenesis markers $\left.{ }^{[35]}\right)$.

In certain publications, the main objective was to highlight specific molecule signalling or specific pathways ${ }^{[2,29,31,34,37-46]}$. The intention of these studies was not to obtain functional bone tissue-engineered constructs, but rather to have better fundamental understanding of bone response to solicitations.

In addition to differentiation, general cell properties were often investigated, such

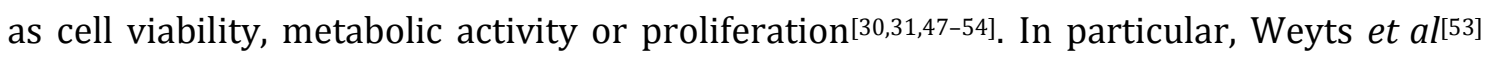
proposed an extensive study of cell apoptosis with a cross-analysis of mechanical signals and differentiation. Cell morphology, more particularly alignment, was also a focus in several publications ${ }^{[48,49,55-57]}$. Cell alignment could indeed improve bone growth and differentiation, an anisotropic tissue[58]. Finally, Struewer et al[36] specifically studied the influence of mechanical solicitations on cell detachment. 


\subsubsection{Biomaterials}

We refer here to scaffolds when specific 2D or 3D biomaterials were used in addition to a standard substrate to perform and enhance cell cultures. The majority of the studies used only a standard culture surface (membrane, plate, bottom of a well or a dish), sometimes with a coating to improve cell adhesion (collagen or fibronectin, see for instance $\left.{ }^{[43]}\right)$. When using scaffolds, degradation rate, overall biocompatibility and degradation products remain crucial parameters to ensure a successful integration in the body[59-63].

Here, scaffolds were knitted ${ }^{[49]}$ or electrospun[64] polymer fibres (respectively polyethylene terephthalate and polycaprolactone), fibrin or collagen gels $[30,41,65,66]$, a $3 \mathrm{D}$ collagen structure[47], or a nanostructure obtained by lithography[56]. Nevertheless, these biomaterials were not used as active culture structures capable of monitoring cell behaviour, and the effect of their morphology on the transmission of mechanical solicitations was not analysed. Mechanical solicitations remained the main way of monitoring cell development in these studies. Only Prodanov et al[56] studied the impact of a nanostructured surface on cell behaviour, concluding that synergy could appear between a relevant nanostructure and mechanical loading. Bruinink et al[49] compared the results of cell-seeded scaffolds with nude ones to estimate variations in its mechanical properties due to the presence of living tissue.

\subsubsection{Environment: tensile loading application}

Different devices were proposed to apply tensile loading at the cell scale through the deformation of samples. Regarding the culture substrate itself (besides an additional scaffold as seen above), it was possible to distinguish three cases: culture wells on elastic plates (16 papers), direct culture on dishes / plates / elastic membranes (15), or a specific culture chamber (6). Extensive reviews of the different mechanical loading devices and 
bioreactors have been proposed[14,20,21,67]. Here, the application of tensile loading to the living tissue were performed with 4-point bending (8 papers), by applying negative pressure to the substrate (13), by mounting the samples directly into clamps (11), or with specific designs (3). Overall, the geometry of the systems was not highly diversified, but to date there is no gold standard. Commercial devices may by a range of magnitude and frequency values or when specific scaffolds have to be used. The articles using scaffolds confirmed this, with 7 out of 8 publications using original or custom-made devices.

\subsection{Main aims when applying tensile loading in vitro}

All the publications aimed to analyse the influence of mechanical loading on cell behaviour, but more detailed objectives can also be highlighted, with two main trends (Figure 1G). On the one hand, articles focusing on understanding cell response mechanisms under mechanical solicitations mostly occurred in the early years (before $2001)^{[26,40-44,50,68-70]}$. On the other, the exploitation of the potential of these cell responses for clinical applications ${ }^{[45,66]}$ and tissue engineering ${ }^{[36,38]}$ started in the last decade, with the first publication in the eponymous journal[65] in 2010. 7 out of the 8 papers using a scaffold were published in the second half of the studied period (after 2001). This highlights a logical shift from fundamental comprehension of bone cell response to external solicitation, to its application for rebuilt tissues and clinical fields by using mechanical loading in vitro before implantation.

\subsection{Culture conditions and loading protocol}

\subsubsection{Dynamic loading}

There was a major consensus on the use of dynamic loading, in particular a sinusoidal signal with a $1-\mathrm{Hz}$ frequency. It was often argued that this value was chosen as a physiological one for everyday life activities i.e. physiological walking $[4,6,9,50,71,72]$. 
The remaining studies differed in frequency with lower values, from $0.05 \mathrm{~Hz}^{[70]}$, to $0.5 \mathrm{~Hz}^{[30,45,53]}$. Tanaka et al[30] was the only one to use a frequency above $1 \mathrm{~Hz}(3 \mathrm{~Hz})$. Bruinink et al[49] used a frequency of $0.01 \mathrm{~Hz}$ as a physiological value for rest periods, which was in fact close to the solicitation frequency chosen by Cillo et al[70] $(0.05 \mathrm{~Hz})$. Significant results were nevertheless obtained with this low value.

In contrast with frequency, the maximum magnitude varied considerably from one study to another (reported either as a microstrain unit ( $\mu$ strain) or an elongation percentage $(1,000 \mu$ strain $=0.1 \%))$. When different strains were successively applied to the same sample during the experiment, only the maximum value was considered in the analysis. Magnitude distribution is shown in. Most of the articles used a magnitude of less than $25,000 \mu$ strain $(2.5 \%$ elongation), in particular from 1,000 to $5,000 \mu$ strain $(0.1$ to 0.5\%), which is indeed considered to be a physiological range[13,44,73] (Figure S2, supporting data). Bone resorption occurs at less than $200 \mu$ strain, a physiological range is up to 2,500 $\mu$ strain (walking and running generate 400 and $950 \mu$ strain in humans, respectively[7,9,50]), an overused window with increasing formation is up to 5,000 $\mu$ strain and pathological overloading above[13].

However, many studies used loading protocols outside of this physiological window. Bruinink et al[49] first specified that a 20,000 $\mu$ strain would be a "macroscopic strain", enabling the easy detection of the in vitro response to a magnitude greater than the usual in vivo response. Zhu et al[74] used the same strategy and multiplied the values obtained by finite element modelling by 20 before in vitro culture to ensure cell response. With deformation over the physiological range, it may become possible to compare physiological and pathological behaviours[26]. Nevertheless, it remains important to limit magnitudes under a threshold that would lead to cell death and bone resorption[49]. The maximum magnitude could also be limited by the behaviour of the substrate itself: we 
could assume that plastic deformation of the scaffold under solicitations would have an impact on the culture and loading applied to the cells. It should therefore be avoided.

Most of the articles studying several magnitudes actually compared physiological and higher values. Cell response peaked around the physiological range in terms of prostaglandin E2 (PGE2) production[26], proliferation ${ }^{[40,52]}$ or ALP production ${ }^{[51]}$. However, an upturn sometimes appeared for the higher values, for instance a second peak of PGE2 production above $28,000 \mu$ strain $^{[26]}$ or a fibrous response in addition to proliferation above $10,000 \mu$ strain $^{[40]}$. For Murray et al[26], these results showed the repair mechanisms which may occur in the failure range. In other articles, the parameters analysed remained stable for any range of magnitude for cell viability[52], proliferation [53] or apoptotic response ${ }^{[53]}$. Finally, some responses shifted, highlighting the difficulty in adapting in vivo principles to in vitro experiments. For instance, Thomas et al[68] found an ALP production peak for $230 \mu$ strain (compared to 35 and $2500 \mu$ strain), lower than expected[68]. The shift often occurred towards higher values, as found by Jagodzinski et al[75] (ALP, osteocalcin and Cbfa1 production for 80,000 $\mu$ strain), Koike et al[51] (proliferation, 150,000 $\mu$ strain), Zhu et al[74] (osteocalcin, collagen, runx2 production, 32,000 $\mu$ strain), Prodanov et al[56] (continuously increased alignment from 10,000 to 80,000 $\mu$ strain) and Matsugaki et al[55] (alignment peak, 40,000 $\mu$ strain).

\subsubsection{Duration of the dynamic culture phase}

The dynamic culture phase lasts from the very first mechanical load to the last cycle, even if rest periods occurred between these points. Most of the studied articles (around $40 \%$ ) belong to two groups: a very short ( $<1$ hour) or a long ( 1 day -7 days) dynamic culture period. Short times may be more suitable for studying the early cell response to tensile loading, with regular sampling, whereas long experiments make it possible to study overall tissue reconstruction. 
Certain articles detailed a comparison between different durations, either for short times $[57,70]$, or several days or even weeks ${ }^{[48,54,64]}$. The results showed that some parameters, especially gene expressions, had non-monotonic variations with a peak at a specific duration[57,70], while other values continuously increased or decreased (respectively mechanical properties ${ }^{[64]}$ and metabolic activity[48]). Connelly et al[65] suggested that these different behaviours may have occurred because of successive effects and different mechanism triggers, and thus noted the need for both short and long term studies. For instance, cell response began with an increase in the production of proteins and proteoglycans, then this production decreased and an increase in collagen production occured[65].

As these non-monotonic variations sometimes occurred for a very short time, it was therefore interesting to use high sampling even for long term studies, because quick adaptive responses could be missed (for instance gradual or cyclic responses), just as the real period of a periodic signal could be lost if the sampling did not satisfy the NyquistShannon theorem[76], classically respected in electronics and signal acquisition and processing.

\subsubsection{Rest periods}

In vivo studies suggested that cell sensitivity to tensile loading could saturate, but is quickly recovered[6,77,78]. This means that cells are able to recover their capacity to translate mechanical signals into a specific biological response after a short or very short rest period[6,77,78]. Many studies mimicked this concept in vitro, using different rest periods schedules (Figure 1H) but several exceptions could be noticed. In particular, Baker et al[64] and Bruinink et al[49] did not use complete rest periods but left the samples respectively under agitation or with low-frequencies solicitations $(0.01 \mathrm{~Hz})$. However, they referred to these phases as "resting phase"[49]. We could assume that this method also mimicked in 
vivo behaviour, where cells never experience complete rest, due to muscle tone, body's own weight or normal micro-movements[79].

\section{Conclusion}

To date, there is no standard protocol for applying tensile loading to in vitro cell cultures, nor any specific protocol depending on target applications or cell sources. However, for certain technical parameters, optimized and consensual ranges of values could be highlighted and appeared to be both relevant and efficient (summary table S1). The analyses of schedules and technical parameters allowed us to highlight "optimal" values, i.e. protocols which led to huge differences in the biological response compared to unstrained control groups while, in the best cases, bone differentiation was triggered. As an overall analysis, a 1-Hz sinusoidal signal in the physiological range seems relevant in most cases for preventing cell death and detachment while triggering bone cell differentiation, maturation and functions. Short dynamic phases separated by rest periods, for instance 600 cycles (10 minutes) of stretching every 6 hours, should allow cells to recover their sensitivity which can fade after a moderate number of cycles. A 24-hour static pre-culture expansion stage should also be considered, in particular when a scaffold is used, to ensure cell attachment.

In contrast, other parameters could be seen as irrelevant and showed decreases in cell viability or cell numbers. In particular, an out-of-range magnitude could lead to undesirable effects, such as no cell response below specific loading (300 $\mu$ strains in contrast with $3,000 \mu$ strains and more ${ }^{[40]}$ ) or a decrease in cell alignment ${ }^{[55]}$ and proliferation ${ }^{[52]}$ for high magnitudes.

The analysis was conducted here for tensile loading devices and bone tissue applications, and the main conclusions could be used as a tool to help in decision-making 
in the development of future experiments. The technical parameters were often guided by in vivo results or physiological values, but moving to out-of-range conditions did not necessarily have a negative impact, especially when the main objectives were to obtain a rebuilt tissue. It appeared furthermore that a slide from studies of fundamental mechanisms to tissue engineering applications may be occurring. We can expect this shift to be strengthened in the future as tissue engineering processes start to reach clinical applications. Moreover, there is now a growing interest for the regeneration of interfaces and composite tissues, complex hybrid systems ${ }^{[80]}$. Mechanical solicitations will require accurate optimisation to monitor the growth of several cell lineages simultaneously in addition to bone, such as ligament[81].

\section{Acknowledgement}

Timothée Baudequin acknowledges the financial support of the CNRS and the Collegium INSIS-UTC.

\section{Conflict of interest}

The authors declare no conflict of interest.

\section{References}

[1] P. Ducy, Science (80-. ). 2000, 289, 1501.

[2] J. Klein-Nulend, R. G. Bacabac, M. G. Mullender, Pathol. Biol. 2005, 53, 576.

[3] J. Wolff, 1892.

[4] H. M. Frost, Anat. Rec. 1987, 219, 1.

[5] S. H. McBride, M. J. Silva, Bonekey Rep. 2012, 1, 192.

[6] C. Rubin, L. Lanyon, J Bone Jt. Surg Am 1984, 66, 397.

[7] C. T. Rubin, Calcif. Tissue Int. 1984, 36, 11.

[8] L. E. Lanyon, C. T. Rubin, J. Biomech. 1984, 17, 897.

[9] L. E. Lanyon, W. G. Hampson, A. E. Goodship, J. S. Shah, Acta Orthop. Scand. 1975, 46, 256.

[10] E. H. Burger, J. Klein-Nulend, FASEB J. 1999, 13 Suppl, S101.

[11] M. Mullender, A. J. El Haj, Y. Yang, M. A. van Duin, E. H. Burger, J. Klein-Nulend, Med. 
Biol. Eng. Comput. 2004, 42, 14.

[12] P. Ehrlich, L. Lanyon, Osteoporos. Int. 2002, 688.

[13] R. L. Duncan, C. H. Turner, Calcif. Tissue Int. 1995, 57, 344.

[14] B. Carpentier, P. Layrolle, C. Legallais, Int. J. Artif. Organs 2011, 34, 259.

[15] L. S. Nair, S. Bhattacharyya, C. T. Laurencin, in Nanotechnologies Life Sci., Wiley-VCH Verlag GmbH \& Co. KGaA, Weinheim, Germany, 2007, pp. 1-16.

[16] C. Li, C. Vepari, H.-J. Jin, H. J. Kim, D. L. Kaplan, Biomaterials 2006, 27, 3115.

[17] K. F. B. Payne, I. Balasundaram, S. Deb, L. Di Silvio, K. F. M. Fan, Br. J. Oral Maxillofac. Surg. 2014, 52, 7.

[18] A. Khademhosseini, Micro and Nanoengineering of the Cell Microenvironment: Technologies and Applications, Artech House, Incorporated, 2008.

[19] F. J. Hughes, W. Turner, G. Belibasakis, G. Martuscelli, Periodontol. 2000 2006, 41, 48.

[20] T. D. Brown, J. Biomech. 2000, 33, 3.

[21] B. D. Riehl, J.-H. Park, I. K. Kwon, J. Y. Lim, Tissue Eng. Part B. Rev. 2012, 18, 288.

[22] J. R. Vetsch, R. Müller, S. Hofmann, J. Tissue Eng. Regen. Med. 2015, 9, 903.

[23] A. B. Yeatts, J. P. Fisher, Bone 2011, 48, 171.

[24] J. Rauh, F. Milan, K.-P. Günther, M. Stiehler, Tissue Eng. Part B. Rev. 2011, 17, 263.

[25] M. S. Thompson, S. R. Abercrombie, C.-E. Ott, F. H. Bieler, G. N. Duda, Y. Ventikos, Biomech. Model. Mechanobiol. 2011, 10, 559.

[26] D. W. Murray, N. Rushton, Calcif. Tissue Int. 1990, 47, 35.

[27] N. Basso, J. N. M. Heersche, Bone 2002, 30, 347.

[28] H. Petite, V. Viateau, W. Bensaïd, A. Meunier, C. de Pollak, M. Bourguignon, K. Oudina, L. Sedel, G. Guillemin, Nat. Am. 2000, 959.

[29] R. Smalt, F. T. Mitchell, R. L. Howard, T. J. Chambers, Am. J. Physiol. 1997, 273, E751.

[30] S. M. Tanaka, J. Li, R. L. Duncan, H. Yokota, D. B. Burr, C. H. Turner, J. Biomech. 2003, $36,73$.

[31] N. Boutahar, A. Guignandon, L. Vico, J. Biol. Chem. 2004, 279, 30588.

[32] Z. Zhong, X.-L. Zeng, J.-H. Ni, X.-F. Huang, Eur. J. Orthod. 2011, 1.

[33] D. Wang, K. Christensen, K. Chawla, G. Xiao, P. H. Krebsbach, R. T. Franceschi, J. Bone Miner. Res. 1999, 14, 893.

[34] C. T. Kao, T. H. Huang, H. Y. Fang, Y. W. Chen, C. F. Chien, M. Y. Shie, C. H. Yeh, J. Bone Miner. Metab. 2016, DOI 10.1007/s00774-015-0690-2.

[35] Y. Guo, Y. Wang, Y. Liu, H. Wang, C. Guo, X. Zhang, C. Bei, Chinese J. Traumatol. 2015, $18,150$.

[36] J. Struewer, P. P. Roessler, K. F. Schuettler, V. Ruppert, T. Stein, N. Timmesfeld, J. R. J. Paletta, T. Efe, Int. Orthop. 2014, 38, 1083.

[37] V. J. Armstrong, M. Muzylak, A. Sunters, G. Zaman, L. K. Saxon, J. S. Price, L. E. Lanyon, J. Biol. Chem. 2007, 282, 20715.

[38] V. David, A. Martin, M. H. Lafage-Proust, L. Malaval, S. Peyroche, D. B. Jones, L. Vico, A. Guignandon, Endocrinology 2007, 148, 2553.

[39] G. L. Galea, A. Sunters, L. B. Meakin, G. Zaman, T. Sugiyama, L. E. Lanyon, J. S. Price, FEBS Lett. 2011, 585, 2450.

[40] D. B. Jones, H. Nolte, J. G. Scholubbers, E. Turner, D. Veltel, Biomaterials 1991, 12, 101.

[41] a Kawata, Y. Mikuni-Takagaki, Biochem. Biophys. Res. Commun. 1998, 246, 404.

[42] A. Miyauchi, K. Notoya, Y. Mikuni-Takagaki, Y. Takagi, M. Goto, Y. Miki, T. TakanoYamamoto, K. Jinnai, K. Takahashi, M. Kumegawa, et al., J. Biol. Chem. 2000, 275, 3335.

[43] M. a Peake, L. M. Cooling, J. L. Magnay, P. B. Thomas, a J. El Haj, J. Appl. Physiol. 2000, 89, 2498.

[44] a a Pitsillides, S. C. Rawlinson, R. F. Suswillo, S. Bourrin, G. Zaman, L. E. Lanyon, 
FASEB J. 1995, 9, 1614.

[45] M. C. Qi, J. Hu, S. J. Zou, H. Q. Chen, H. X. Zhou, L. C. Han, Int. J. Oral Maxillofac. Surg. 2008, 37, 453.

[46] A. Sunters, V. J. Armstrong, G. Zaman, R. M. Kypta, Y. Kawano, L. E. Lanyon, J. S. Price, J. Biol. Chem. 2010, 285, 8743.

[47] S. Diederichs, S. Bo, A. Peterbauer, C. Kasper, T. Scheper, J. Biomed. Mater. Res. A 2010, 94A, 927.

[48] C. Huang, M. Chen, T. Young, J. Jeng, Y. Chen, J. Cell. Biochem. 2009, 1273, 1263.

[49] a Bruinink, D. Siragusano, G. Ettel, T. Brandsberg, F. Brandsberg, M. Petitmermet, B. $\mathrm{Mu}$, J. Mayer, E. Wintermantel, Biomaterials 2001, 22, 3169.

[50] D. Kaspar, W. Seidl, C. Neidlinger-Wilke, a. Ignatius, L. Claes, J. Biomech. 2000, 33, 45.

[51] M. Koike, H. Shimokawa, Z. Kanno, J Bone Min. Metab 2005, 23, 219.

[52] C. Neidlinger-Wilke, H. J. Wilke, L. Claes, J. Orthop. Res. 1994, 12, 70.

[53] F. a a Weyts, B. Bosmans, R. Niesing, J. P. T. M. Van Leeuwen, H. Weinans, Calcif. Tissue Int. 2003, 72, 505.

[54] M. Li, X. Li, M. C. Meikle, I. Islam, T. Cao, Tissue Eng. Part A 2013, 19, 2130.

[55] A. Matsugaki, N. Fujiwara, T. Nakano, Acta Biomater. 2013, 9, 7227.

[56] L. Prodanov, J. te Riet, E. Lamers, M. Domanski, R. Luttge, J. J. W. a van Loon, J. a. Jansen, X. F. Walboomers, Biomaterials 2010, 31, 7758.

[57] Z. Zhong, X. Zeng, J. Ni, X. Huang, Eur. J. Orthod. 2011, 35, 59.

[58] M. V Jose, V. Thomas, K. T. Johnson, D. R. Dean, E. Nyairo, Acta Biomater. 2009, 5, 305.

[59] S. C. Rizzi, D. J. Heath, a G. Coombes, N. Bock, M. Textor, S. Downes, J. Biomed. Mater. Res. 2001, 55, 475.

[60] D. Depan, B. Girase, J. S. Shah, R. D. K. Misra, Acta Biomater. 2011, 7, 3432.

[61] D. W. Hutmacher, Biomaterials 2000, 21, 2529.

[62] C. Zhou, S. Jin, R. Willing, Biomech. Model. Mechanobiol. 2016, 15, 1685.

[63] V. Dhote, F. J. Vernerey, Biomech. Model. Mechanobiol. 2014, 13, 167.

[64] B. M. Baker, R. P. Shah, A. H. Huang, R. L. Mauck, Tissue Eng. Part A 2011, 17, 1445.

[65] J. T. Connelly, E. J. Vanderploeg, J. K. Mouw, C. G. Wilson, M. E. Levenston, Tissue Eng. Part A 2010, 16, 1913.

[66] A. Charoenpanich, M. E. Wall, C. J. Tucker, D. M. K. Andrews, D. S. Lalush, D. R. Dirschl, E. G. Loboa, Tissue Eng. Part A 2014, 20, 67.

[67] I. Martin, D. Wendt, M. Heberer, Trends Biotechnol. 2004, 22, 80.

[68] G. P. Thomas, a. J. El Haj, Calcif. Tissue Int. 1996, 58, 101.

[69] G. Zaman, a a Pitsillides, S. C. F. Rawlinson, R. F. L. Suswillo, J. R. Mosley, M. Z. Cheng, L. a M. Platts, M. Hukkanen, J. M. Polak, L. E. Lanyon, J. Bone Miner. Res. 1999, $14,1123$.

[70] J. E. Cillo, R. Gassner, R. R. Koepsel, M. J. Buckley, Oral Surg. Oral Med. Oral Pathol. Oral Radiol. Endod. 2000, 90, 147.

[71] H. M. Frost, Bone Miner. 1992, 19, 257.

[72] A. E. Goodship, J. Kenwright, J. Bone Joint Surg. Br. 1985, 67, 650.

[73] J. You, C. E. Yellowley, H. J. Donahue, Y. Zhang, Q. Chen, C. R. Jacobs, J. Biomech. Eng. 2000, $122,387$.

[74] J. Zhu, X. Zhang, C. Wang, X. Peng, X. Zhang, Int. J. Mol. Sci. 2008, 9, 2322.

[75] M. Jagodzinski, M. Drescher, J. Zeichen, S. Hankemeier, C. Krettek, U. Bosch, M. van Griensven, Eur. Cell. Mater. 2004, 7, 35.

[76] E. C. Shannon, Proc. IRE 1949, 37, 10.

[77] A. G. Robling, F. M. Hinant, D. B. Burr, C. H. Turner, J. Bone Miner. Res. 2002, 17, 1545.

[78] D. B. Burr, a G. Robling, C. H. Turner, Bone 2002, 30, 781. 
[79] Y. Shafieyan, K. Tiedemann, S. V. Komarova, T. M. Quinn, J. Biomech. 2014, 47, 3750.

[80] T. Baudequin, M. Tabrizian, Adv. Healthc. Mater. 2018, 7, 1700734.

[81] H. A. Benhardt, E. M. Cosgriff-hernandez, D. Ph, Tissue Eng. Part B. Rev. 2009, 15, 467. 
Table 1. Detailed summary of the articles studied.

\section{Table 1. Detailed summary of the articles studied}

\begin{tabular}{|c|c|c|c|c|c|}
\hline Author & Year & Cell Type & Origin & Device & Scaffold \\
\hline Murray & 1990 & Osteoblasts, Calveria & Mouse & $\begin{array}{l}\text { Wells on elastic slides, } \\
\text { vertical, clamps }\end{array}$ & No \\
\hline Jones & 1991 & $\begin{array}{l}\text { Periostal cells, Hav cells, } \\
\text { Osteoblast-like cells }\end{array}$ & Bovine & $\begin{array}{l}\text { Wells on elastic slides, } \\
\text { horizontal, 4-point bending }\end{array}$ & No \\
\hline $\begin{array}{r}\text { Neidlinger- } \\
\text { Wilke }\end{array}$ & 1994 & Femur or tibia osteoblasts & human & $\begin{array}{l}\text { Elastic silicon dishes, } \\
\text { horizontal, clamps }\end{array}$ & No \\
\hline Pitsillides & 1995 & Osteocytes from tibiotarsi & Chick & $\begin{array}{l}\text { Elastic plastic strips, } 4- \\
\text { point bending }\end{array}$ & No \\
\hline Thomas & 1996 & Bone marrow cells & Rat & $\begin{array}{c}\text { membrane bases of dishes, } \\
\text { horizontal }\end{array}$ & No \\
\hline Smalt & 1997 & $\begin{array}{l}\text { Calvarial cells, long bone cells, } \\
\text { MC3T3-E1 , UMR-106-01 and } \\
\text { ROS } 17 / 2.8\end{array}$ & Rat & $\begin{array}{l}\text { Tissue culture-treated strip } \\
\text { of polystyrene film } \\
\text { withayer of flexible silicone } \\
\text { sealant, horizontal, }\end{array}$ & No \\
\hline Kawata & 1998 & Frontal and parietal bone cells & Rat & Flexcell & Collagen gel \\
\hline Zaman & 1999 & $\begin{array}{l}\text { Long bone-derived osteoblast- } \\
\text { like cells and calvarial-derived } \\
\text { osteoblast-like cells }\end{array}$ & Rat, chick & $\begin{array}{l}\text { Plastic strips, 4-point } \\
\text { bending }\end{array}$ & No \\
\hline Kaspar & 2000 & Femoral or tibial osteoblasts & Human & $\begin{array}{l}\text { Elastic culture dish, } \\
60 * 30 \mathrm{~mm} \text {, horizontal, } 4- \\
\text { point bending }\end{array}$ & No \\
\hline Cillo & 2000 & Osteoblast-like cell SaOS-2 & Human & Flexcell & No \\
\hline Miyauchi & 2000 & Osteocytes & Rat, chick & Flexcell & No \\
\hline Peake & 2000 & $\begin{array}{l}\text { Osteoblast-like cells and MG-63 } \\
\text { human osteosarcoma cells }\end{array}$ & Human & $\begin{array}{l}\text { Collagen and fibronectin } \\
\text { coated coverslips, 4-point } \\
\text { bending }\end{array}$ & No \\
\hline
\end{tabular}




\begin{tabular}{|c|c|c|c|c|c|}
\hline Author & Year & Cell Type & Origin & Device & Scaffold \\
\hline You & 2000 & $\begin{array}{l}\text { Foetal osteoblasts SV40-hFOB } \\
1.19\end{array}$ & Human & $\begin{array}{c}\text { Coated silicon membrane, } \\
\text { horizontal, clamps }\end{array}$ & No \\
\hline Bruinink & 2001 & Bone marrow cells & Rat & $\begin{array}{l}\text { Custom-made micro } \\
\text { tensile apparatus }\end{array}$ & Knitted PET mat \\
\hline Tanaka & 2003 & MC3T3-E1 cells & Mouse & $\begin{array}{l}\text { Tension/compression } \\
\text { chamber filled with cells- } \\
\text { gel composite (piston-like) }\end{array}$ & Collagen gels \\
\hline Weyts & 2003 & Foetal osteoblasts SV40-HFO & Human & Flexcell & No \\
\hline Jagodzinski & 2004 & Bone marrow stromal cells & Human & $\begin{array}{c}\text { Rectangular, elastic } \\
\text { silicone dishes, horizontal, } \\
\text { clamps }\end{array}$ & No \\
\hline Boutahar & 2004 & ROS 17/2.8, MC3T3-E1 cells & Rat, mouse & Flexcell & No \\
\hline Koike & 2005 & $\begin{array}{l}\text { Bone marrow stromal cell line } \\
\text { ST2 }\end{array}$ & Mouse & Flexcell & No \\
\hline David & 2007 & Mesenchymal stem cells & Bovine & Flexcell & No \\
\hline \multirow[t]{2}{*}{ Armstrong } & 2007 & ROS $17 / 2.8$ cells & Rat & $\begin{array}{l}\text { Custom-made plastic } \\
\text { strips, 4-point bending }\end{array}$ & No \\
\hline & 2008 & Bone marrow cells & Rat & $\begin{array}{l}\text { 4-point bending apparatus } \\
\text { with flexible silicon- } \\
\text { bottomed chambers }\end{array}$ & No \\
\hline Zhu & 2008 & SV40 osteoblasts & Human & Flexcell & No \\
\hline Huang & 2009 & Mesenchymal stem cells & Human & Flexcell & No \\
\hline Sunters & 2010 & $\begin{array}{l}\text { UMR-106 cells, fibroblasts and } \\
\text { osteoblasts }\end{array}$ & Rat, mouse & $\begin{array}{l}\text { Custom-made plastic } \\
\text { strips, 4-point bending }\end{array}$ & No \\
\hline Connelly & 2010 & Bone marrow stromal cells & Calf & $\begin{array}{l}\text { Chambers filled with fibrin } \\
\text { hydrogels, horizontal, } \\
\text { clamps }\end{array}$ & Fibrin gel \\
\hline
\end{tabular}




\begin{tabular}{|c|c|c|c|c|c|}
\hline Author & Year & Cell Type & Origin & Device & Scaffold \\
\hline Diederichs & 2010 & $\begin{array}{c}\text { Adipose tissue-derived } \\
\text { mesenchymal stem cells, MG- } \\
63 \text { cells }\end{array}$ & Human & $\begin{array}{c}\text { Rectangular, elastic silicon } \\
\text { dishes in a stimulation } \\
\text { apparatus, horizontal, } \\
\text { clamps }\end{array}$ & $\begin{array}{l}\text { 3D samples: } 2 \\
\text { mm-thick } \\
\text { collagen scaffolc } \\
\text { (MG 63) }\end{array}$ \\
\hline Prodanov & 2010 & $\begin{array}{l}\text { Bone marrow mesenchymal } \\
\text { stem cells }\end{array}$ & Rat & Horizontal, clamps & $\begin{array}{c}\text { Lithography } \\
\text { nanostructured } \\
\text { silicon }\end{array}$ \\
\hline Galea & 2011 & Saos 2 cells & Human & $\begin{array}{l}\text { Custom-made plastic } \\
\text { strips, } 4 \text { points bending }\end{array}$ & No \\
\hline Baker & 2011 & $\begin{array}{l}\text { Tibial and femoral bone } \\
\text { marrow stem cells }\end{array}$ & Calf & $\begin{array}{l}\text { Custom-made medium } \\
\text { chamber, horizontal, } \\
\text { clamps }\end{array}$ & $\begin{array}{l}\text { Aligned PCL } \\
\text { electrospun } \\
\quad \text { fibers }\end{array}$ \\
\hline Zhong & 2011 & MС3T3-E1 cells & Mouse & $\begin{array}{l}\text { Silicone membrane, } \\
\text { horizontal, clamps. }\end{array}$ & No \\
\hline $\mathrm{Li}$ & 2013 & Embryonic stem cells & Human & Flexcell & No \\
\hline Matsugaki & 2013 & Calvariae osteoblasts & Mouse & Silicon chamber & No \\
\hline Struewer & 2014 & $\begin{array}{l}\text { Bone marrow osteoblast-like } \\
\text { cells, tail tendon derived } \\
\text { fibroblasts }\end{array}$ & Rat & Flexcell & No \\
\hline \multirow[t]{2}{*}{ Charoenpanich } & 2014 & Mesenchymal stem cells & $\begin{array}{l}\text { Human } \\
\text { (osteoporotic } \\
\text { donors) }\end{array}$ & Flexcell & $3 \mathrm{D}$ collagen gels \\
\hline & 2015 & $\begin{array}{l}\text { Osteoblasts, bone marrow- } \\
\text { derived mesenchymal stem } \\
\text { cells and RAW } 264.7 \text { cells }\end{array}$ & Rat, mouse & 4-point bending & No \\
\hline Kao & 2016 & Monocytes & Human & $\begin{array}{c}\text { Commercial vacuum } \\
\text { system }\end{array}$ & No \\
\hline
\end{tabular}


A

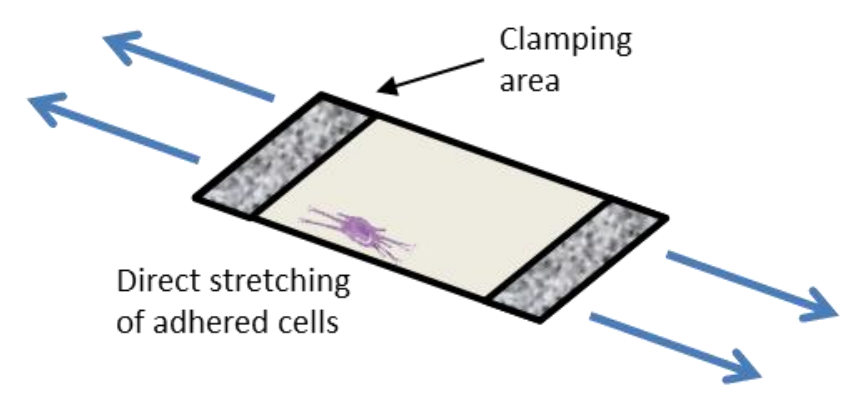

B

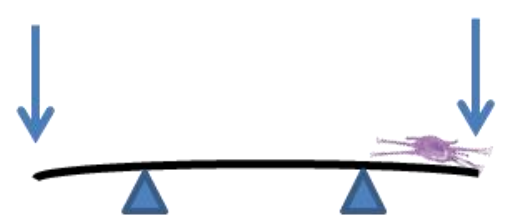

Tensile loading due to substrate deformation under compression

C
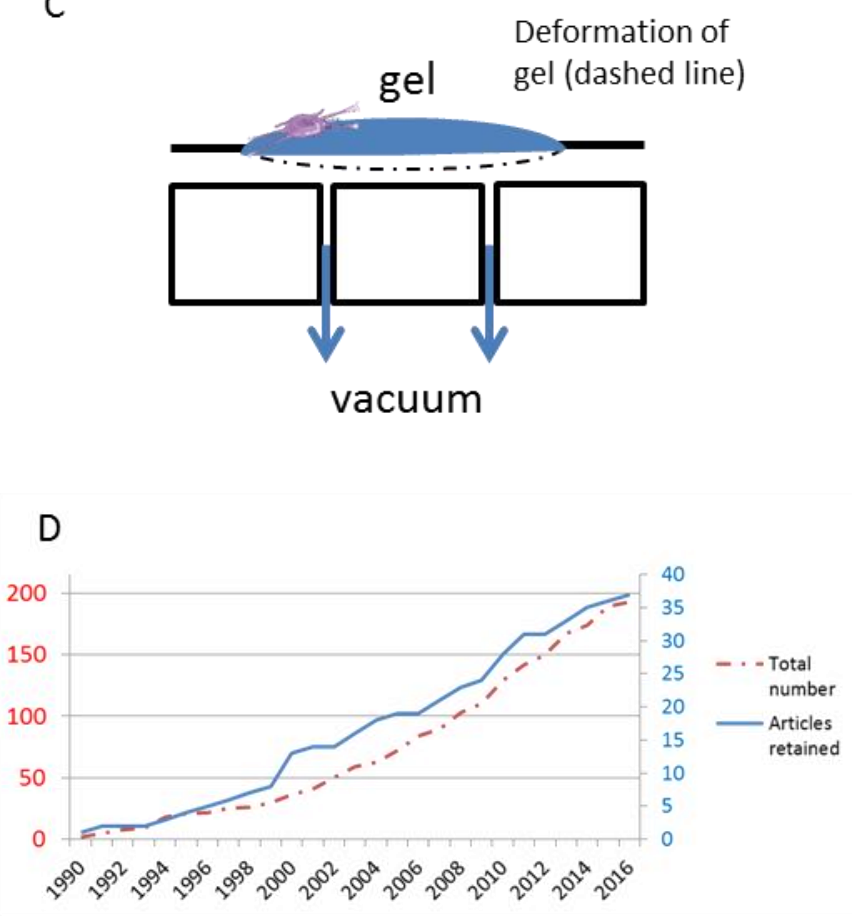

E

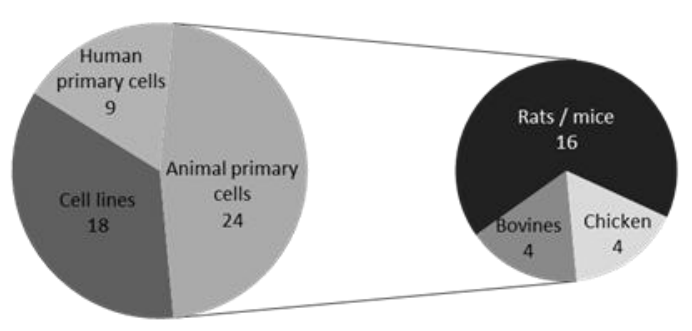

$\mathbf{F}$

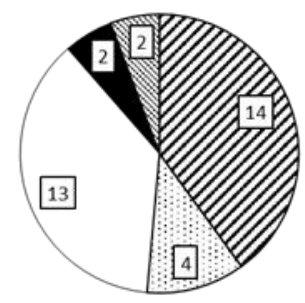

Z Osteoblasts (-like) DOsteocytes (-like)

$\square$ Stem cells

- Fibroblasts

هonocytes

G

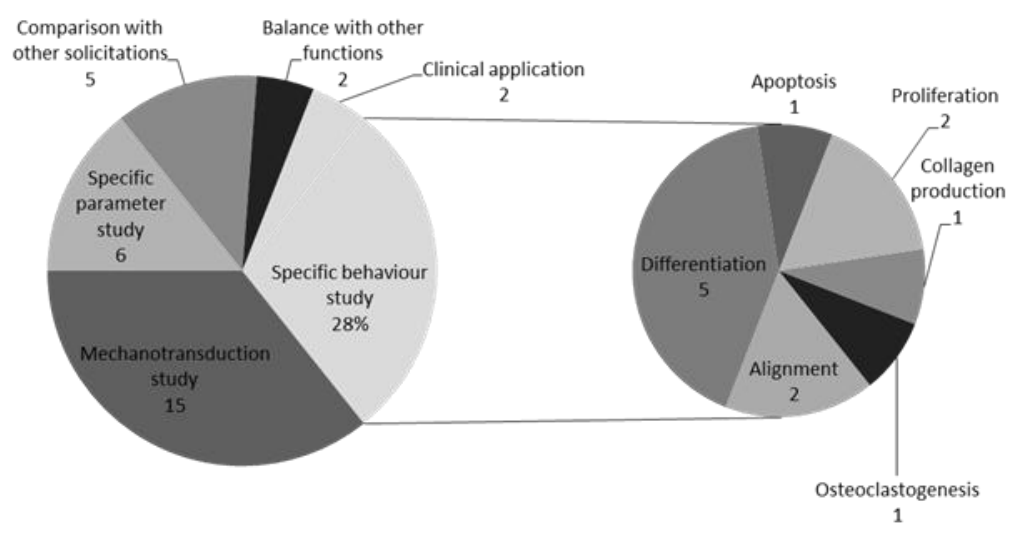

$\mathrm{H}$

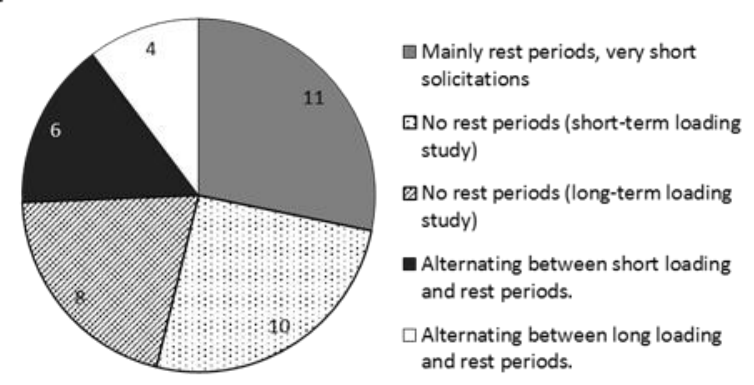

Figure 1: Examples of cell tensile loading, with uniaxial stretching into clamps (A), 4-point bending (B) or gel matrix and vacuum (C). Adapted from Brown et al[20] and Flexcell ${ }^{\circ}$ documentation. D: Cumulative distribution of the articles retained (blue line) and of the total number of publications with the keywords "bone tensile mechanical loading in vitro" according to Scopus (red line). Distribution of (E) cell sources regarding species, origins (primary cells / cell lines), (F) differentiation states and functions, (G) the main objectives as announced in the respective introductions (some studies announced several objectives) and $(\mathrm{H})$ the different ways of applying rest periods to cell cultures in vitro. 


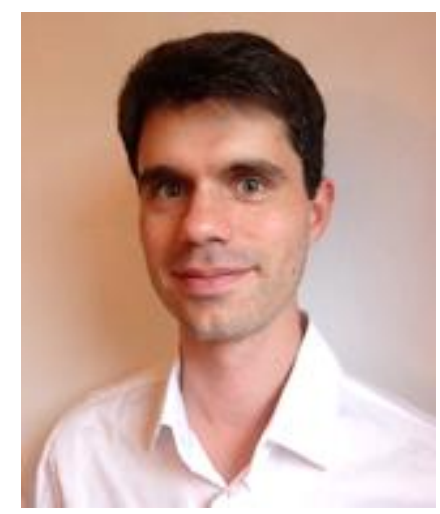

Timothée Baudequin received his Ph.D. in Biomechanics and Bioengineering from the Université de Technologie de Compiègne in 2015. His research focused on the development of scaffolds for the generation of tissue-engineered bone substitutes for the maxilla-facial area. He has a strong interest in the influence of chemical, biological, and mechanical signals on stem cell differentiation and the resultant synergistic effects. He recently started a post-doctoral position at the Institute of Biomedical Engineering of the University of Oxford.

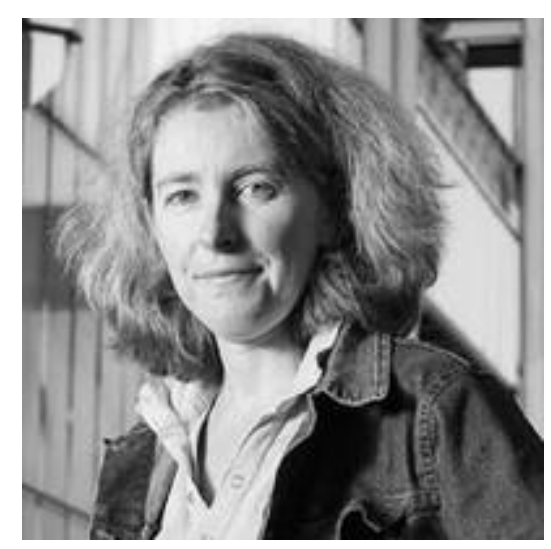

Cécile Legallais is Director of Research at CNRS, and currently head of the UMR CNRS 7338 Biomechanics \& Bioengineering at the Université de Technologie de Compiègne. Bronze Medal from the CNRS in 2003, she focuses her research on the design and characterisation of (bio)artificial organs, combining experimental and modelling approaches at different scales. More specifically, she has worked on external bioartificial liver since 15 years, dealing with the microencapsulation of hepatic cells in alginate for use in a fluidized bed 
bioreactor. More recently, she also developed tissue engineering approaches for the reconstruction of musculo-skeletal tissues.

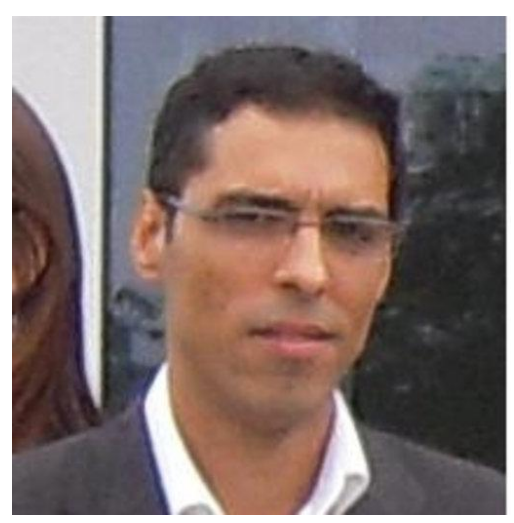

Fahmi BEDOUI is Associate professor at Sorbonne University - Université de Technologie de Compiègne. He focuses his research on the investigation of correlation between process, microstructure and macroscopic behaviour of polymeric materials. More specifically, he has worked intensively on the development of characterization and modelling methods to predict mechanical properties of virgin and nano-reinforced polymers. More recently, he has widen his interest to the understanding of the relationship between material-microstructure and cell response in the fields of tissue engineering in the objective of the reconstruction of musculo-skeletal tissues. 